Fixed Point Theory, 23(2022), No. 1, 219-238

DOI: $10.24193 /$ fpt-ro.2022.1.14

http://www.math.ubbcluj.ro/ nodeacj/sfptcj.html

\title{
SPLIT EQUALITY FIXED POINT PROBLEMS AND COMMON NULL POINT PROBLEMS IN HILBERT SPACES
}

\author{
MOHAMMAD ESLAMIAN*, S. AZARMI** AND G. ZAMANI ESKANDANI** \\ * Department of Mathematics, \\ University of Science and Technology of Mazandaran, \\ P.O.Box: 48518-78413, Behshahr, Iran \\ E-mail: eslamian@mazust.ac.ir, mhmdeslamian@gmail.com \\ ** Department of Pure Mathematics, Faculty of Mathematical Sciences, \\ University of Tabriz, Tabriz, Iran \\ E-mail: s.azarmi@tabrizu.ac.ir, zamani@tabrizu.ac.ir
}

\begin{abstract}
In this paper we introduce and study a new algorithm for finding a solution of the split equality fixed point problem for quasi-nonexpansive mappings and a common zero of a finite family of inverse strongly monotone mappings in Hilbert spaces. A numerical example to support our main theorem will be exhibited. Our results improve and generalize some recent results in the literature.

Key Words and Phrases: Split equality fixed point problems, inverse strongly monotone mappings, null point problem.
\end{abstract}

2020 Mathematics Subject Classification: 47J25, 47N10, 47H10, 65J15.

\section{REFERENCES}

[1] H.H. Bauschke, P.L. Combettes, Convex Analysis and Monotone Operator Theory in Hilbert Spaces, Springer-Verlag, 2011.

[2] D.P. Bertsekas, E.M. Gafni, Projection methods for variational inequalities with applications to the traffic assignment problem, Math. Progr. Study, 17(1982), 139-159.

[3] C. Byrne, Iterative oblique projection onto convex sets and the split feasibility problem, Inverse Problems, 18(2002), 441-453.

[4] C. Byrne, A unified treatment of some iterative algorithms in signal processing and image reconstruction, Inverse Problems, 20(2004), 103-120.

[5] L.C. Ceng, Q.H. Ansari, J.C. Yao, Some iterative method for finding fixed points and solving constrained convex minimization problems, Number Algebra, Control Optim, 1(3)(2011), 341359.

[6] Y. Censor, T. Bortfeld, B. Martin, A. Trofimov, A unified approach for inversion problems in intensity-modulated radiation therapy, Phys. Med. Biol., 51(2006), 2353-2365.

[7] Y. Censor, T. Elfving, A multiprojection algorithms using Bragman projection in a product space, Numerical Algorithms, 8(1994), 221-239.

[8] Y. Censor, A. Gibali, S. Reich, Algorithms for the split variational inequality problem, Numerical Algorithms, 59(2012), 301-323.

[9] M. Eslamian, Strong convergence of split equality variational inequality and fixed point problem, Riv. Mat. Univ. Parma, 8(2)(2017), 225-246. 
[10] M. Eslamian, Hybrid method for equilibrium problems and fixed point problems of finite families of nonexpansive semigroups, Revista de la Real Academia de Ciencias Exactas, Fisicas y Naturales, Serie A. Matematicas, 107(2013), 299-307.

[11] M. Eslamian, G.Z. Eskandani, M. Raeisi, Split common null point and common fixed point problems between Banach spaces and Hilbert spaces, Mediterr. J. Math., 14(3)(2017), 119.

[12] A. Gibali, S. Reich, R. Zalas, Iterative methods for solving variational inequalities in Euclidean space, J. Fixed Point Theory Appl., 17(2015), 775-811.

[13] A. Gibali, S. Reich, R. Zalas, Outer approximation methods for solving variational inequalities in Hilbert space, Optimization, 66(2017), 417-437.

[14] K. Goebel, S. Reich, Uniform Convexity, Hyperbolic Geometry, and Nonexpansive Mappings, Marcel Dekker, New York and Basel, 1984.

[15] H. Iiduka, W. Takahashi, Strong convergence theorems for nonexpansive nonself-mappings and inverse-strongly-monotone mappings, J. Convex Anal., 11(2004), 69-79.

[16] D. Kinderlehrer, G. Stampaccia, An Iteration to Variational Inequalities and their Applications, Academic Press, New York, 1990.

[17] P.E. Mainge, Strong convergence of projected subgradient methods for nonsmooth and nonstrictly convex minimization, Set-Valued Analysis, 16(2008), 899-912.

[18] E. Masad, S. Reich, A note on the multiple-set split convex feasibility problem in Hilbert space, J. Nonlinear Convex Anal., 8(2007), 367-371.

[19] A. Moudafi, Alternating CQ-algorithm for convex feasibility and split fixed-point problems, J. Nonlinear Convex Anal., 15(2014), 809-818.

[20] P.M. Pardalos, Th.M. Rassias, A.A. Khan, Nonlinear Analysis and Variational Problems, Springer, Berlin, 2010.

[21] M. Raeisi, G.Z. Eskandani, M. Eslamian, A general algorithm for multiple-sets split feasibility problem involving resolvents and Bregman mappings, Optimization, 67(2)(2018), 309-327.

[22] M. Raeisi, G.Z. Eskandani, A hybrid extragradient method for a general split equality problem involving resolvents and pseudomonotone bifunctions in Banach spaces, Calcolo 56, 43 (2019), https://doi.org/10.1007/s10092-019-0341-4.

[23] G.Z. Eskandani, M. Raeisi, Solving a general split equality problem without prior knowledge of operator norms in Banach spaces, Results Math., 76(2021), article no. 4, https://doi.org/10.1007/s00025-020-01312-2.

[24] R.T. Rockafellar, R.J.-B. Wets, Variational Analysis, 2nd edition, Springer, New York, 2004.

[25] W. Takahashi, M. Toyoda, Weak convergence theorems for nonexpansive mappings and monotone mappings, J. Optim. Theory Appl., 118(2003), 417-428.

[26] M. Tian, B.N. Jiang, Weak convergence theorem for zero points of inverse strongly monotone mapping and fixed points of nonexpansive mapping in Hilbert space, Optimization, 66(2017), 1689-1698.

[27] H.K. Xu, Viscosity approximation methods for nonexpansive mappings, J. Math Anal Appl., 298(2004), 279-291.

[28] H.K. Xu, Iterative algorithms for nonlinear operators, J. London Math. Soc., 66(2002), 240-256.

[29] I. Yamada, The hybrid steepest descent method for the variational inequality problem over the intersection of fixed point sets of nonexpansive mappings, In: Inherently Parallel Algorithms in Feasibility and Optimization and Their Applications, (D. Butnariu, Y. Censor, and S. Reich Eds.) Amsterdam, Elsevier, 2001, 473-504.

[30] J. Zhao, Solving split equality fixed-point problem of quasi-nonexpansive mappings without prior knowledge of operators norms, Optimization, 64(2015), 2619-2630.

Received: April 18, 2019; Accepted: March 27, 2021. 
SPLIT EQUALITY 